\title{
Smallholder dairy sheep production and market channel development: An institutional perspective of rural Former Yugoslav Republic of Macedonia
}

\author{
M. J. Voors ${ }^{*}$ and M. D'Haese ${ }^{*}{ }^{1}$ \\ *Development Economics Group, Wageningen University, PO Box 8130, 6706 KN Wageningen, the Netherlands \\ †Department of Agricultural Economics, Coupure links 653, 9000 Gent, Belgium
}

\begin{abstract}
The rural economy of the Former Yugoslav Republic of Macedonia has been adapting to new economic and political realities. Especially important for rural areas has been the breakdown of the socialist market structure in agriculture, which meant the demise of cooperative structures and farmers gaining access to new market outlets. The aim of this paper is to investigate the potential of dairy sheep farmers to enter into new contracts with buyers and to analyze why some farmers continue selling to traditional market outlets. Using survey data of dairy sheep farmers we studied the choice they make between 3 market outlets: (1) selling milk to a recently established large dairy processor, (2) selling milk to traditional small local processors, or (3) transforming milk on-farm into cheese and selling it at the farm gate or at local markets. The significance of determinants of choice for these markets were tested in a multinomial logit model, which showed that distance to the collection point of the large dairy processor was the most important determinant of whether farmers sold milk or made cheese, with those at a greater distance selling cheese. Furthermore, we analyzed the main sources of transaction costs in developing new market channels. Overcoming transport and transaction costs may contribute to higher income for the farmers and hence to improving their livelihoods.
\end{abstract}

Key words: dairy sheep, market structure, contracts, transaction costs

\section{INTRODUCTION}

The Former Yugoslavian Republic (FYR) of Macedonia is a landlocked country in the eastern Balkan region. It became independent at the collapse of Yugoslavia in 1991 and counts about 2 million inhabitants (2002 census; SSO, 2005), 30\% of whom live below the

Received September 1, 2009.

Accepted April 13, 2010.

${ }^{1}$ Corresponding author: Marijke.DHaese@UGent.be poverty line in rural areas (World Bank, 2002). After independence in 1991, FYR Macedonia embarked upon an unprecedented economic transition. Major reforms were adopted to dismantle the planned economy in favor of a free market system. Key institutions of the socialist economy such as the central planning organizations were abolished, socially owned enterprises were privatized, and trade liberalization policies opened the economy to the outside world (World Bank, 2003). After an initial downturn of the economy in the early years of transition, the national economy recovered and economic growth was again positive by 1996 (WDI, 2007).

Changes have been especially significant for the often-remote smallholders. Under the socialist regime, smallholders sold their produce to agricultural cooperatives and were, in return, provided with secured access to inputs. Following the demise of the plan economy, market access became more complex and less predefined. For many actors in the food chain, the costs of transacting in factor and output markets are still high and performance of markets is poor. As elsewhere in Eastern Europe, production is low, and after a decade and a half of economic reform, the economy is still characterized by missing and incomplete markets and high degrees of uncertainty (Liefert and Swinnen, 2002), especially in rural areas. Some farmers seem to withdraw from the market and are now opting for low risk investments and low levels of specialization in their production technology, whereas others are found tapping into the new commercial opportunities created by market liberalization. This paper investigates this decision-making process for small dairy sheep producers in FYR Macedonia.

Sheep farming has played a central role in the livelihoods of farmers in FYR Macedonia for centuries. Most native sheep breeds are subsequently well adapted to the dry summers and harsh terrain, at the cost of reduced productivity in both milk and meat (Dzabirski and Andonov, 1997; Gürsoy, 2006; see Haenlein, 2007 for a general overview). The generic breed in FYR Macedonia, which is also common in the rest of the 
Balkans and in the Czech Republic (Haenlein, 2007), consists of 2 strains of Pramenka. The Ovcepolka strain is common in central FYR Macedonia, and the Sharplaninka strain is found mainly in the mountainous areas bordering Albania and Kosovo. Artificial insemination is rarely used by farmers because of the high cost and lack of expertise. A government project that started in the early 1980s introduced cross-breeding with the German Würtemberg breed Merino Landschaf to increase lamb production (MASA, 2001). These cross-breeds of Merino and Pramenka are characterized by better lamb fattening performance and faster development. More recently, high-yielding milk sheep such as East-Friesian and Awassi have been introduced in an effort to boost milk production (Haenlein, 2007). Although these breeds have desirable traits not present in indigenous breeds, they are less able to adapt to local circumstances, such as drought, rough terrain, and walking long distances to pastures. Further disadvantages of these sheep are that their lambs are often rejected by traders and that they require more intensive management (A. van Engelen and A. Depinovska, Lakes O' Lakes Inc., Skopje, Macedonia; unpublished report).

Currently, the number of sheep has been estimated at 1.24 million, although unofficial documents estimate the number at just 0.8 million. Niznikowski et al. (2006) report that the number of sheep in FYR Macedonia, Serbia, and Montenegro has decreased from 2.5 million head in 1995 to 1.2 million head in 2004. Farms have, on average, 100 sheep, although this number differs significantly across the country. Similar to that of traditional sheep farming in Turkey (Gürsoy, 2006), the extensive character of traditional sheep farming in FYR Macedonia is a consequence of the difficult climate, rough terrain, and market uncertainties that force farmers to keep breeds that serve both milk and meat production.

The perishable nature of milk makes secure access to markets crucial for both producers and processors. Market access is regulated through various channels: farmers can sell milk directly to consumers, retailers (e.g., shops, restaurants), and processors or via distributors. Alternatively, milk is processed into cheese on the farm before it is sold at the farm gate, on local markets, to retailers, or to specialized farmers markets. Milk is sold through various arrangements. Typically, processors or distributors organize joint collections at the farm gate or collect milk at specialized milk cooling and collection centers. Farmers also organize themselves in associations or cooperatives to facilitate joint collections or joint processing. Cooperative milk processing is mentioned by Tsourgiannis et al. (2008) as an alternative market channel to local private milk processing and sales to large industrial processors.
In this paper, we focused on the new processing companies for dairy sheep products that have been established in FYR Macedonia in the last 15 yr. As a result, farmers and processors have developed new arrangements to organize the sheep milk supply. These market opportunities are considered important for the survival of the dairy sheep sector in the study area. Farmers are provided an alternative to the traditional market channels; that is, selling milk to small local dairy processing companies (processing on average $<1,000 \mathrm{~L} / \mathrm{d}$ ) or processing the milk into cheese onfarm. Most of the newly created dairy companies are small, family-run companies located in larger farms or towns. One large milk processing company operates in the research area. Mlekara Bitola is located in the city of Bitola in southern FYR Macedonia, and it processes $40 \mathrm{t}$ of sheep and $80 \mathrm{t}$ of cow milk per day. It was privatized in 1994 and has since made substantial investments to improve facilities and enlarge operations. Mlekara Bitola produces a range of processed sheep milk products for the FYR Macedonian market. A substantial part of the sheep milk, however, is pasteurized and sold to Greek processors, meeting shortages on the Greek market (MASA, 2001). Direct export of cheese is constrained because of sanitary rules in export markets (i.e., the European Union) and competition from producers in other countries (i.e., Bulgaria and Greece). In total, Mlekara Bitola receives milk from 850 farmers from southern and eastern FYR Macedonia. This processor has been active in the research villages Sveti Nikole and Stip (and to a minor extent in Kumanovo) since 2001 and has enlarged its scale of operations every year. Since 2002, Mlekara Bitola uses intermediary companies to organize the collection of sheep milk and 4 collection centers operate under contract with Mlekara Bitola. The centers are often located on large farms in the area, and a truck comes once or twice per week to collect milk from each center. In the research area, there were 2 such collection centers, 1 in Amzebegovo in the Sveti Nikole region collecting 5 t of milk per day, and 1 in Suševo in the Stip region collecting 8 t per day.

All 3 market channels operate with different institutional arrangements; cheese is sold on a spot-market, milk is sold to small local processors under informal oral agreements, and milk is sold to large dairy processors under formal written contracts. The success of the contracts offered by the large dairy processor is critical to the supply chain of the modern processing company and essentially hinges on 2 major decisions by the dairy sheep farmers: 1) whether to sell raw milk instead of cheeses produced on-farm, and 2) whether to enter into contracts with the large dairy processors instead of selling to small dairy processors. Arguably, these decisions 
depend on farm and farmer characteristics, different incentives of the contracts, and market cost differentials.

This paper aims to explore the determinants of choice in dairy sheep market relationships. We used a multinomial model to analyze the household, farm, and location determinants of the farmer's choice of selling cheese, milk to small processors, or milk to the large processor. Second, we explored the differentials in transaction costs (i.e., information, negotiation, and monitoring costs) between the different selling arrangements. Following the definition of Hobbs (1997), transaction costs comprise information costs (ex ante costs to obtain price and product information and costs of identifying suitable trading partners), negotiating costs (costs of carrying out the transaction, commission costs, costs of negotiating the trading terms, and costs to make a contract), and monitoring or enforcement costs (ex post costs of ensuring that the terms of trade were respected). See Allen (2000) for an extensive overview on the interpretation of transaction costs in the literature.

As Haenlein (2001) demonstrates, small dairy ruminants have been shown to improve the livelihoods of farmers in both developed (in particular the Mediterranean countries) and developing countries, even under difficult climatic and geographical conditions. Yet, more research is needed to (a) "identify better and promote the marketing of the unique values of dairy products from goat and sheep milk, so to better justify the existence of better prices for their products" and (b) "improve conditions of family livelihood and better net income levels of small ruminant farmers to achieve keeping the farmer and his family content in this enterprise and reduce off-farm migration" (Haenlein, 2001). We aim to address these knowledge gaps by pointing to the obstacles that must be overcome to improve market access of smallholder dairy producers. Other studies have tackled these research questions. A study close to our work by Tsourgiannis et al. (2008) analyzed the factors affecting the marketing channel choice of sheep and goat farmers in Greece for the sales of goat and sheep milk. Four market channels were identified, namely local private milk processing plants, co-operative milk processing plants, large national dairy companies, and the private use of milk. The analysis revealed that farm and farmer's characteristics such as scale of production and level of specialization were important determinants in the selection of market outlets. The authors furthermore argue that factors such as sales price, speed of payment, and loyalty determine market choice. Doyon et al. (2008) analyze milk market channel regulatory mechanisms that could change the distribution of the chain surplus within the dairy supply chain in New England.

\section{MATERIALS AND METHODS}

\section{Data}

For our empirical analysis, we drew from a data set of 90 dairy sheep farming households that we collected. The data set contained information on (1) household and farm characteristics, (2) market channel characteristics, and (3) transport and transaction costs. The data collection took place in from April to June 2005 and covered information on 2004 and early 2005.

A multistage sampling approach was followed (Poate and Daplyn, 1993); 3 municipalities-Sveti Nikole, Stip, and Kumanovo - were chosen based on their differences in geography and farming populations. In each of these municipalities, 30 farmers were randomly selected from a government list of registered sheep farmers through simple random sampling. In total, 87 farms were used in the analysis; 3 farms were dropped because of missing data.

\section{Estimation Framework}

The data analysis consisted of 3 parts. First, we described the characteristics of farms in relation to location and sales market. Second, we analyzed the importance of farm, family, and location characteristics on market choice. We used a multinomial logit model, in which the dependent variable is the market choice, $\left.Y_{i}: 1\right)$ the sale of milk to small dairy processors, 2) milk sale to a large dairy processor, or 3) the sales of cheese at spot markets and farm-gate. This choice or "output of decision" is conditioned by a set of exogenous variables $x_{i}$, including household characteristics (size of the household, dependency ratio, and education level), farm characteristics (number of sheep in the flock, number of years the farm has been owned, and breed of sheep kept), and location characteristics (distance to collection center).

The model estimates the following probability for the market decisions, whereby $j$ s are the markets chosen and $x_{i}$ are the determinants of choice (Greene, 2000):

$$
\operatorname{Prob}(Y=j)=\frac{e^{\beta_{j}^{\prime} x_{i}}}{1+\sum_{k=1}^{J} e^{\beta_{k} x_{i}}}
$$

for $j=1,2, \ldots J$, and

$$
\operatorname{Prob}(Y=0)=\frac{1}{1+\sum_{k=1}^{J} e^{\beta_{k}{ }^{\prime} x_{i}}},
$$

Journal of Dairy Science Vol. 93 No. 8, 2010 
with $Y$ being the market choice $j$ made among a total of $J$ different markets, $x_{i}$ the exogenous determinants of this choice of household $i$ with coefficient $\beta$. The parameters were estimated using maximum likelihood estimation. We refer to Greene (2000) for the econometric background on the model.

The following definitions were used for the exogenous variables $x_{i}$. The size of household was defined as the number of people staying permanently in the household; the dependency ratio was calculated by dividing the sum of children and elderly in the household by the household size. Both variables check the importance of family labor on market choice. The education level was reflected by a dummy, taking 1 if a farmer achieved at least a primary education (4 yr). The farm characteristics considered the number of milking sheep in the flock and the number of years the farm had been owned. In the multinomial logit model, we considered 2 dummies for owning Merino and Pramenka/Merino cross-breeds, respectively. Finally, to assess the location of the farm toward market possibilities, the distance to the collection center of the large processor was added to the model. The distance to the collection center of the large processor reflects the remoteness of the farms to the market place for selling fresh milk to the large dairy company. We included this variable to check if being distant from the collection center made it more difficult for farmers to sell to the large dairy company. We argue that with this distance, transaction costs may also increase. The further the farm is removed from the collection center, the more difficult it may be to establish regular contact with the large dairy.

Third, we studied the influence of transaction costs on contract choice. Transaction costs have proven difficult to calculate (Masten, 1996), and potential endogeneity problems arise in the analysis of market choices because the level of transaction costs is not independent of the choice between alternative markets. First, transaction costs are not easily observed; it is not possible to calculate hypothetical transaction costs for institutional arrangements that are not chosen; thus, transaction costs that a single manager can face in alternative organizational arrangements cannot be quantified ex ante. Second, the data needed to compare organizational forms are not easily quantifiable. An analysis of transactions would be more significant if the attributes of the transaction could be related to data on the organizational form or contract arrangements (Masten, 1996). Transaction and transport costs are closely linked to the choice for a certain market arrangement or contract, where farmers are expected to choose the contract that is the most rewarding and "least costly" in terms of ex ante or expected transaction costs. However, the choice of market outlet results in transaction costs, at least some of which are not foreseen at the time the choice is made. When using survey data, the transaction costs observed, or their attributes, are then more the resultants of the contract choice made than the determinants of choice themselves. Therefore, an instrumental variable approach, which is generally used to overcome such 2-way causality problems in econometrics, to include transaction costs in the multinomial model is not applicable in this study, because what we measure is conceptually different from the perceived costs on which the farmer bases his or her market decision. Instead, we applied a comparative approach. Williamson (1979) suggested that the importance of transaction costs in the choice for trade relationships could best be described in terms of certain observable attributes, where $t$-tests and chisquared estimates are used to explain the partial differences between the different institutions.

\section{RESULTS}

\section{Dairy Sheep Farming}

Table 1 summarizes the main socioeconomic data of the sheep farmers. The descriptive data show several differences between the 3 municipalities, Sveti Nikole, Stip, and Kumanovo. The key difference between the municipalities was flock size. Although farmers in $\mathrm{Ku}-$ manovo and Stip were comparable in terms of most household characteristics (education and size), farmers in Kumanovo kept substantially smaller flocks. Likely, this is due to the mountainous character of the landscape, limiting the scope for intensive sheep farming. Also, and perhaps as a result, there is some indication of a rural exodus: farmers in Kumanovo were significantly older and had fewer dependants. In contrast, farms in Stip were significantly larger, with some of the larger commercial farms managing more than 1,000 sheep.

With regard to the sheep breeds kept by farmers, just under half $(46 \%)$ owned the Pramenka-Merino cross-breed and $29 \%$ kept the Pramenka breed. A few farmers specialized in the Merino breed $(16 \%)$ or other breeds such as Awassi or Friesian (7\%). Although Merino sheep generally have higher fertility rates, comparing productivity across the breeds did not result in significant differences in performance in the sample.

The yearly sheep cycle is driven by climate and lamb sales possibilities. Lambs are usually born in January and February, fed on ewe's milk, and sold for both domestic and export markets during the Catholic and Orthodox Easter period around the end of March through April. After weaning, sheep are milked until July or August; this is when pastures become depleted and yields drop below $0.5 \mathrm{~L} / \mathrm{d}$. Yet, the main source of income for farmers is the periodic sale of lambs (in 
Table 1. Respondent characteristics over study municipalities ${ }^{1}$

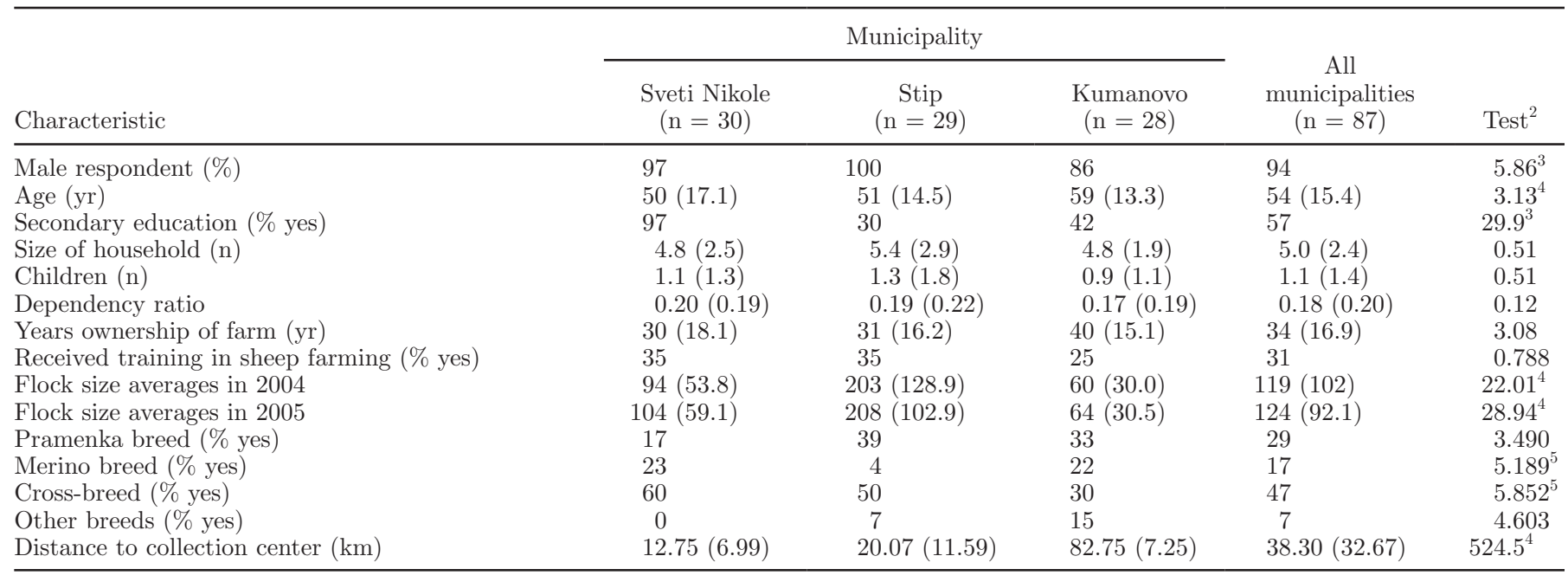

${ }^{1}$ Standard deviation in parentheses, where applicable.

${ }^{2} F$-statistics reported for continuous variables; chi-squared statistics reported for categorical variables.

${ }^{3}$ Chi-squared statistic is significant $(P<0.01)$.

${ }^{4}$ Means within a row differ $(P<0.01)$.

${ }^{5}$ Means within a row differ $(P<0.05)$.

Slovakia, the sale of lambs is next in importance to milk production; Wolfová et al., 2009). Wool sales are incidental, mostly because of the low quality of the wool produced (MASA, 2001). Sheep milk and cheese products are sold on a domestic market because export markets are inaccessible due to sanitary requirements
(MASA, 2001). The average percentages of income derived from selling lamb and sheep, dairy products, and wool are listed in Table 2.

For the production of dairy products, sheep are milked twice a day (early morning and late afternoon) and milk is sold to 2 types of buyers (Figure 1): small

Table 2. Comparison of dairy channels between locations ${ }^{1}$

\begin{tabular}{|c|c|c|c|c|c|}
\hline \multirow[b]{2}{*}{ Item } & \multicolumn{3}{|c|}{ Municipality } & \multirow{2}{*}{$\begin{array}{c}\text { All } \\
\text { municipalities } \\
(\mathrm{n}=87)\end{array}$} & \multirow[b]{2}{*}{ Test $^{2}$} \\
\hline & $\begin{array}{l}\text { Sveti Nikole } \\
\quad(\mathrm{n}=30)\end{array}$ & $\begin{array}{c}\text { Stip } \\
(\mathrm{n}=29)\end{array}$ & $\begin{array}{l}\text { Kumanovo } \\
(\mathrm{n}=28)\end{array}$ & & \\
\hline \multicolumn{6}{|c|}{ Income derived from selling sheep products $2004(\%)$} \\
\hline Sales from live animals ${ }^{3}$ & $56.6(13.5)$ & $61.6(15.5)$ & $61.5(20.6)$ & $59.9(16.8)$ & 0.77 \\
\hline Sales from dairy products & $42.6(13.6)$ & $37.2(15.8)$ & $37.8(20.5)$ & $39.1(16.9)$ & 0.84 \\
\hline Sales of wool & $0.76(0.48)$ & $1.25(0.67)$ & $0.71(0.60)$ & $0.92(0.64)$ & $6.89^{4}$ \\
\hline Cheese & 20 & 35 & 57 & 37 & $15.17^{5}$ \\
\hline Milk sold to small dairies ${ }^{6}$ & 40 & 35 & 18 & 31 & \\
\hline Milk sold to large dairies & 37 & 28 & 11 & 25 & \\
\hline Not participating in market & 3 & 3 & 14 & 7 & \\
\hline \multicolumn{6}{|c|}{ Dairy market participation 2005 (\% within location) } \\
\hline Cheese & 12 & 0 & 77 & 29 & $47.43^{7}$ \\
\hline Milk sold to small dairies & 40 & 14 & 23 & 27 & \\
\hline
\end{tabular}

${ }^{1}$ Standard deviation in parentheses, where applicable.

${ }^{2} F$-statistics reported for continuous variables; chi-squared statistics reported for categorical variables.

${ }^{3}$ Refers to the income from regular sales of lamb meat; incidental sales of adult sheep and rams are not included.

${ }^{4}$ Means within a row differ $(P<0.05)$.

${ }^{5}$ Chi-squared statistic is significant $(P<0.05)$.

${ }^{6}$ Farmers who sold both cheese and milk are counted as milk selling and divided according to the type of contracts they have with the dairy processor. In the sample, 8 farmers who sold milk to the small dairies also indicated to sell cheese and 7 farmers combined milk sales to large dairies with cheese.

${ }^{7}$ Chi-squared statistic is significant $(P<0.01)$. 


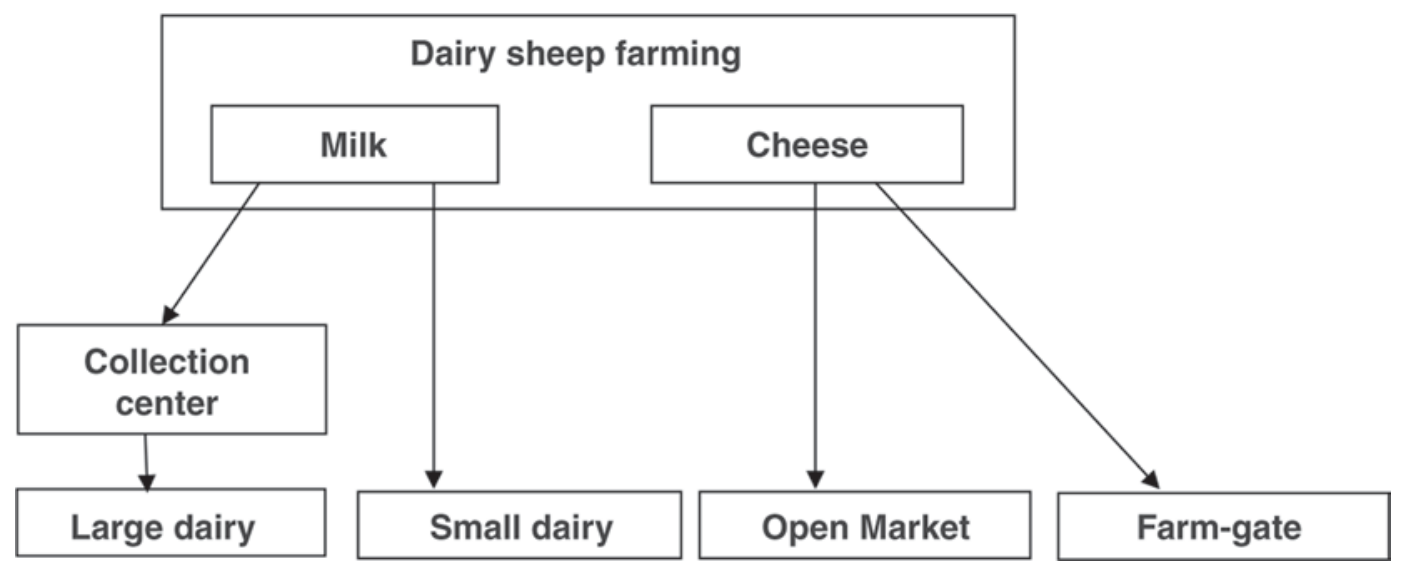

Figure 1. Schematic organization of main marketing channels.

traditional dairies processing $<1,000 \mathrm{~L} / \mathrm{d}$, on average, and large (more modern) dairies processing up to 40,000 L/d (GS, 2003).

If milk is not sold, cheese is made after each milking and kept at the farm for up to 3 mo, after which it is sold on open markets and, in some cases, at the farm gate. It is common for farmers to produce at least some cheese for home consumption, mainly at the beginning and end of the milking season when daily quantities of milk are low. The cheese is sold in containers in which cheese is preserved with brine. In our sample, most farmers produced a young white cheese (called feta). A minority also produced a more aged yellow cheese (called kashkaval). Herein, we focused our analysis on the feta cheese. At the time of research, the average price per kilogram of feta was 185 (SD 28.3) FYR Macedonian Dinar (MKD) $/ \mathrm{kg}(1 \mathrm{US} \$=51.59 \mathrm{MKD}$, as of January 1,2006 ) with a range from $125 \mathrm{MKD} / \mathrm{kg}$ for farmers selling in open markets to $500 \mathrm{MKD} / \mathrm{kg}$ for farmers selling at the farm gate. The variation in price was also significant between the regions. On average, prices were the highest in Sveti Nikole $(206 \mathrm{MKD} / \mathrm{kg})$, and prices in Stip were significantly lower (171 MKD/ kg; F-statistic: 5.214; $P<0.01)$.

In 2004, most of the farmers in Kumanovo produced and sold cheese; Stip had the second largest number of farmers producing and selling cheese (Table 2). In Sveti Nikole, most farmers sold milk to either a small or a large dairy company. It is interesting to note that although 15 farmers in the sample produced both milk and cheese in 2004, all farmers specialized in a single market in 2005, with several farmers changing their market choice between the 2004 and 2005 seasons. In 2005, an increasing number of farmers in Sveti Nikole and Stip started selling milk to the large dairy company, whereas in Kumanovo, more farmers produced cheese and none sold to the large dairy company.

\section{Determinants of Market Choice}

Table 3 compares the characteristics of farmers supplying to the 3 marketing outlets in 2004. Here we excluded those farmers who did not participate in any of these markets. The partial analysis in Table 3 did not reveal a difference in family size or dependency ratio (these variables were included in the model to check for differences in the availability of family labor between the marketing channels). Also, we would have expected the number of years a farmer was engaged in sheep farming to differ, but the partial test reveals that this factor was not significant. Experience in sheep farming may be both a contributor and a deterrent to participation in the modern milk market. For example, young farmers may not be as familiar with sheep farm management compared with older farmers. Yet, because they gained most of their experience after the collapse of socialism, younger farmers may actually be more capable of adapting to new market realities, entering into modern formal contracting arrangements more easily. There is some indication that education levels do play a role in the choice of agricultural activity: farmers selling cheese had significantly lower levels of education compared with the farmers selling milk.

We considered the distance of the farm to the collection center as an important farm characteristic. It is fair to argue that a distance measure not only captures transport costs but also proxies the transaction costs that a farmer faces. As discussed earlier, we have left out the direct measurements of transaction costs because of their inherent endogeneity with a specific market choice (we return to this below), but it is obvious that proximity to the market reduces costs of searching, contracting, and enforcement. As Table 3 shows, the average distance for farms selling milk to the collection center was significantly smaller, and cheese-producing 
Table 3. Comparison of characteristics per marketing channel in $2004^{1}$

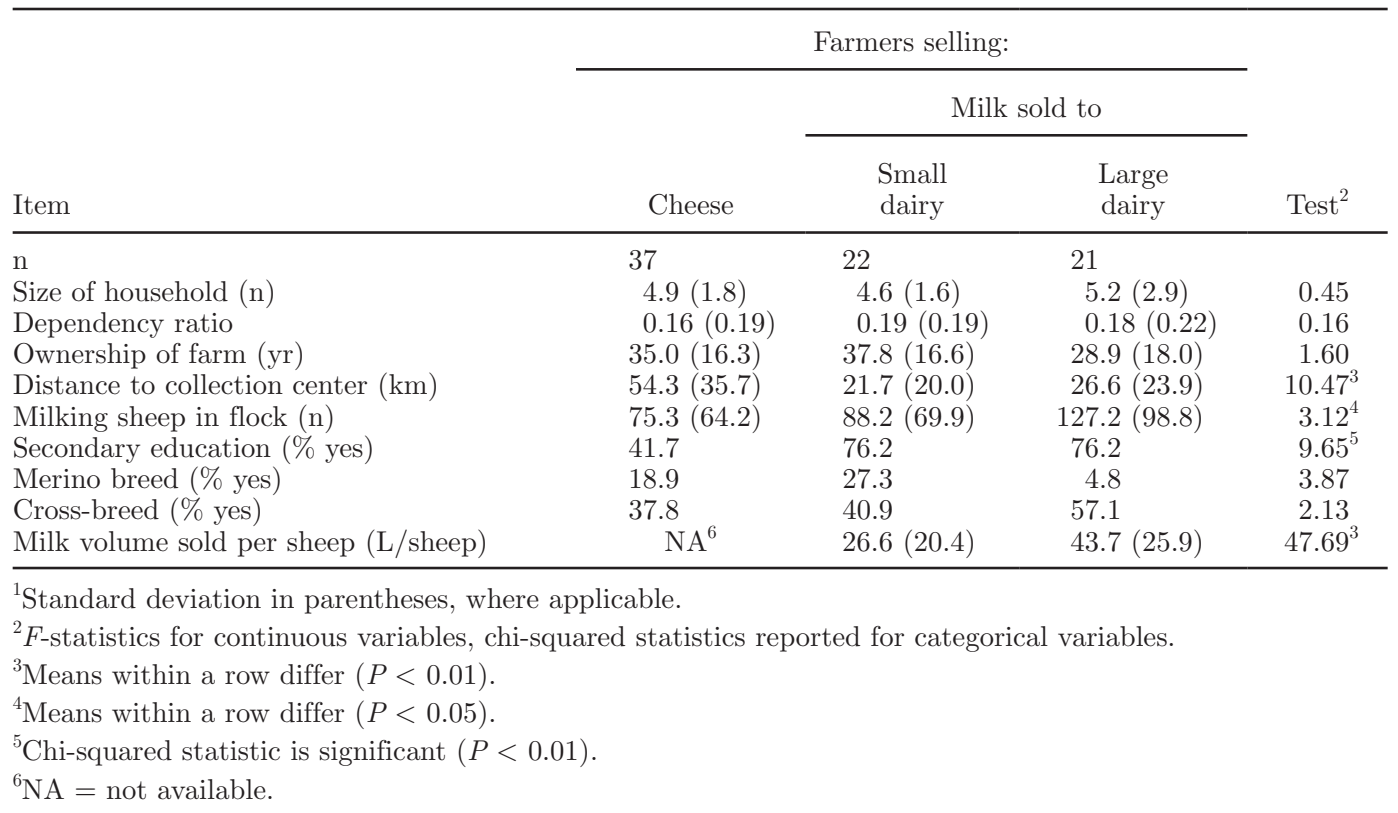

farms were located a greater distance from the collection center. As will be discussed in the next section, milk is only collected directly on the farm in a small fraction of farms.

Finally, flock size and the use of an improved crossbreed sheep (Pramenka and Merino) may influence milk market participation. Cheese-producing farms are often smaller compared with milk-selling farms in FYR Macedonia. However, there was no significant difference in the composition of flocks in terms of breed (Merino or cross-breeds; Merino breeds are more suitable for wool production). Table 3 does not show the records of volume of milk sold by farmers selling cheese, because farmers used different cheese-making techniques that differed in the amount of milk used. However, it is interesting to note the difference in milk volume sold per sheep between farmers selling to the large dairy and those selling to smaller dairies. This is a reflection of sheep management because it indicates that farmers selling to the large dairy company own sheep with improved yields and that they market more milk and keep less for home consumption.

The length of the milking season for most respondents was slightly less than 6 mo. However, substantial variation exists in farm management. Some farmers have regulated yearly cycles, meaning that most sheep deliver lambs around the same time (January-February), which are weaned after $65 \mathrm{~d}$, and subsequently milked for $175 \mathrm{~d}$. These farmers reach a maximum milk yield after a few months and dry off their ewes in the summer. Other farms have less regulated breeding schedules and continuously have their flock in various stages of the cycle; the variance in weaning and milking period is substantial: weaning varied from 45 to $98 \mathrm{~d}$ and milking between 60 and $311 \mathrm{~d}$.

The multinomial estimates of market choice are presented in Table 4. The likelihood ratio of the chisquared test was large (43.36) and significant (at a 99\% confidence level) indicating that the model was statistically significant. A Hausman test confirmed the independence of irrelevant alternatives (Greene, 2000).

The regression results show that distance to the collection center significantly explained the choice of farmers to produce and sell milk (to small and large dairy processors) compared with producing cheese; the greater the distance to the collection center, the lower the probability that farmers sold milk instead of cheese. This confirms the findings above (Table 2) and fits with the observation that remote farmers face high transport costs to reach markets. Because milk is a bulky product and spoils rapidly, it cannot be transported across great distances without cooled transport; consequently, remote farmers more often produced and sold cheese. This resonates with findings reported elsewhere (see e.g., Staal et al., 1997; Holloway et al., 2000). Second, a smaller distance to the large dairy processor could enhance sales with formal contracts because proximity arguably reduces not only transport costs but also other costs related to the transaction: information gathering may be easier, negotiation more frequent, and monitoring less costly.

Level of education positively influenced the probability that a farmer sold milk to the large dairy company. From a transaction costs perspective, this makes sense 
Table 4. Multinomial estimates for market choice $^{1}$

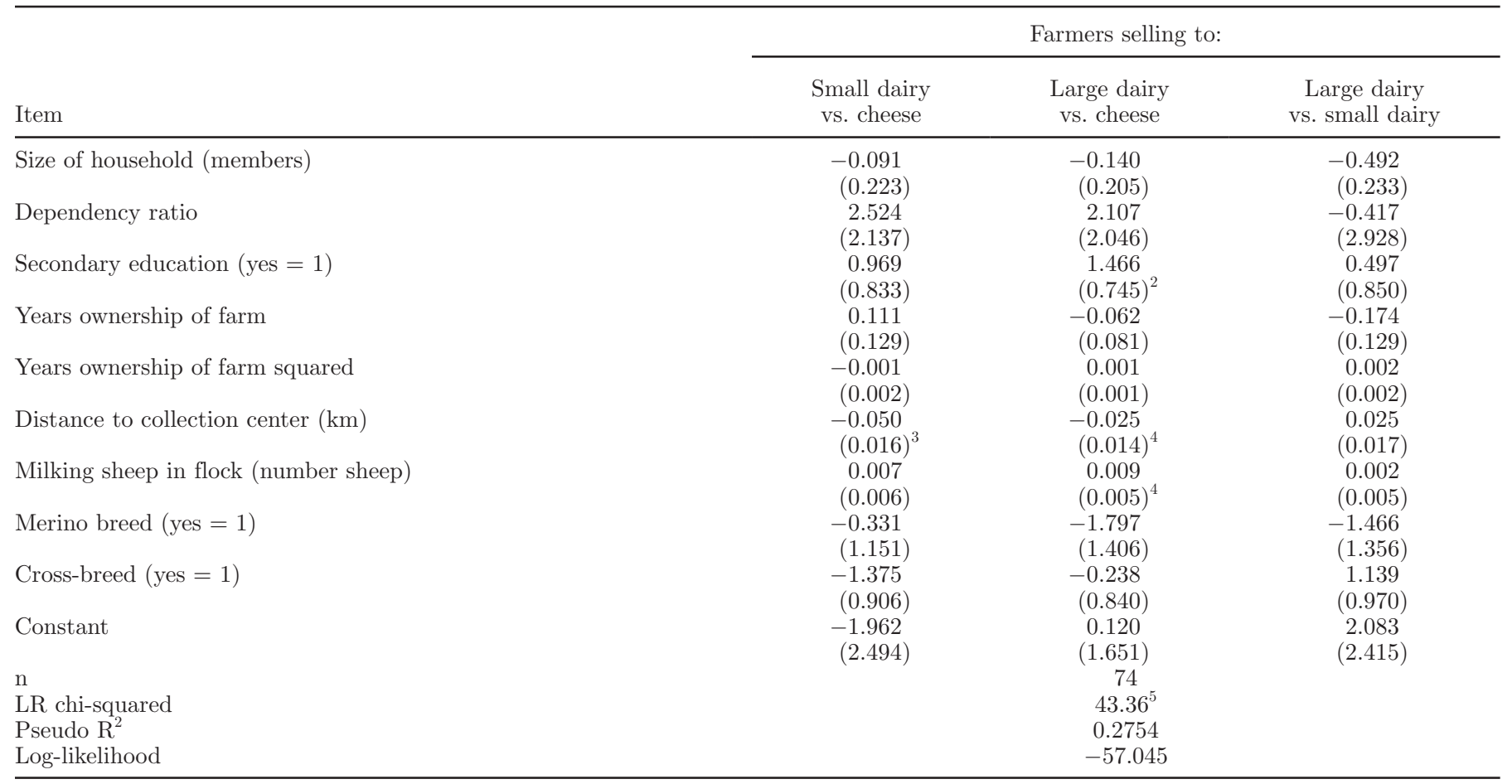

${ }^{1}$ Standard error in parentheses.

${ }^{2}$ Coefficient is statistically different from zero $(P<0.05)$.

${ }^{3}$ Coefficient is statistically different from zero $(P<0.01)$.

${ }^{4}$ Coefficient is statistically different from zero $(P<0.10)$.

${ }^{5}$ Likelihood ratio $(\mathrm{LR})$ chi-squared is statistically significant $(P<0.01)$.

because more educated farmers are likely more comfortable making contracts with buyers, negotiating about conditions, and learning about prices elsewhere, and are more adept at ensuring the agreement is enforced. As a robustness check, we included a measure for whether farmers had received training in sheep farm management, which did not change the results.

Flock size also positively influenced the probability that a farmer sold milk to the large dairy company, suggesting that economies of scale in transport and contracting were important determinants of market participation.

It is surprising that experience did not influence market choice. In line with the influences of education, experience determines the ability of an individual to adapt to the market environment and to take on new market opportunities. However, given the observation that farmers had, on average, $30 \mathrm{yr}$ of experience (Table 3 ), its variance may be too small to result in significant differences.

Contrary to expectation, no significant variables explained the differences between farmers selling milk to small or large dairy companies. We argue that the choice of these farmers for their respective contracts could be explained by other characteristics of the transaction, which we will explore in the next section.

\section{Comparing Market Channels on Transport and Transaction Costs}

Several studies show that transaction costs in milk trade are high because of the perishable nature of milk and the costs of measuring quality (Staal et al., 1997; Holloway et al., 2000). Raw milk requires rapid transportation and cooled storage or it needs to be processed into less perishable forms. This perishability and seasonality of milk production limit marketing options, especially for small and remote producers.

Contracts in Milk Sales. In the multinomial model, no determinants were significant enough to explain the choice of farmers to sell to large or to small dairy companies. In this section, we explore an alternative explanation by comparing the transaction cost attributes of the contracts in milk sales (between farmers and small dairies and farmers and the large dairy). These transaction costs result from differences of the institutional arrangement governing milk transactions. The large dairy used formal written contracts 
Table 5. Comparison of transaction costs characteristics in the milk market channels

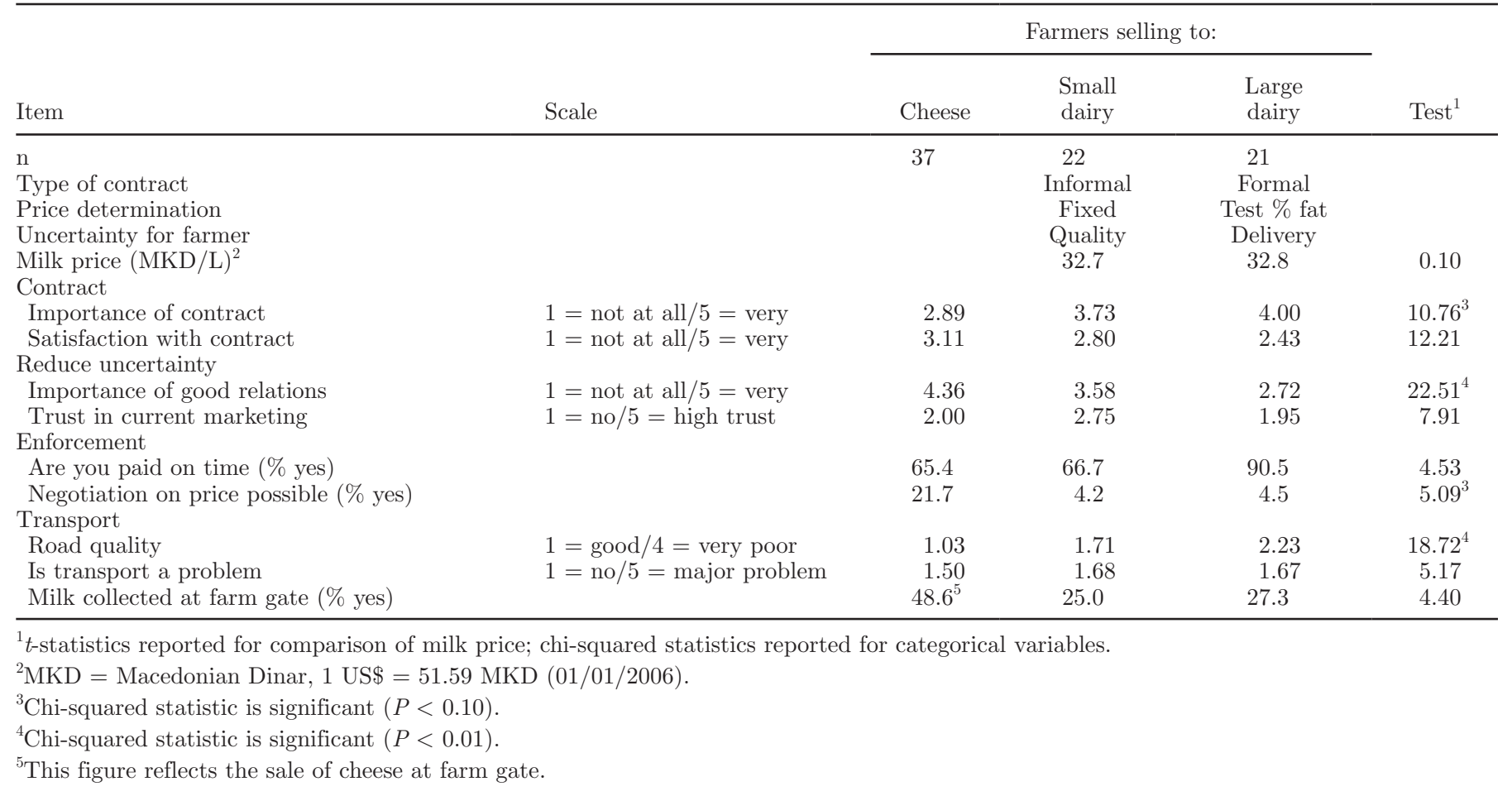

exclusively, whereas farmers and small processors made informal oral agreements (Table 5).

The key difference between the milk market channels was the way in which the milk prices were determined. The large dairy company used a grading system to determine milk quality in fat content and level of bacterial contamination, and farmers were paid monthly based on the milk they had supplied during that time. Small processors lacked the technical capabilities and financial means to test milk quality and therefore applied a fixed price. The difference in pricing system did not result in significantly different prices, although the price offered by small dairies was less variable $(30-36$ MKD/L) than the price paid by the large dairy (24-38 $\mathrm{MKD} / \mathrm{L})$.

Most farmers selling to small dairies expressed that they were satisfied with their current contracts. In contrast, only one-third of the farmers selling to the large processor indicated that they were satisfied with their contract. More farmers selling to the large processor attached greater importance to the contracts they had compared with the farmers selling to the small processor. The contracts with large dairies were formal and therefore more restrictive than those with small processors. In contrast, having better social relations was more important for farmers selling to small processors; the informal contracts seemed to be built more on trust and were less the result of formal negotiations.
Apart from the negotiation costs, farmers and processors incurred transaction costs because of the monitoring of quality levels; the contracts between famers and the large and small processors were different in these respects, resulting in varying levels of transaction costs but also in deviating sources of opportunistic behavior, especially for the small processors. Because the latter worked with fixed milk prices, farmers were paid for the quantity of milk they delivered, but the milk volume delivered was sometimes increased by adding water or cow milk. The fact that quality was not checked by the small processor provided an extra motivation for the development of trust in these relationships.

A prime source of uncertainty for the farmers was the risk of being paid late, primarily because of small processors experiencing liquidity problems. Farmers generally accepted these delays because they trusted the small processors; the majority of farmers expressed that they did not run the risk of not being paid at all. The large processor usually paid on time; only $10 \%$ of the farmers experienced delayed payments.

The distance to the collection center did not contribute to the probability of selling to the large processor compared with the small processor. Milk was collected at the farm for $27 \%$ of farms selling to the large processor and for $25 \%$ of those selling to small processors. Others transported milk to the collection points using vehicles, horses, or mules, with the farmers selling the 
Table 6. Sources of transaction costs in the milk market

\begin{tabular}{|c|c|c|}
\hline Dairy size & Search and contract costs & Enforcement costs \\
\hline Small & $\begin{array}{l}\text { Entering contract }=\text { high } \\
\text { Maintaining contract }=\text { high }\end{array}$ & $\begin{array}{l}\text { Price = low } \\
\text { Milk delivery = high } \\
\text { Payment }=\text { high }\end{array}$ \\
\hline Large & $\begin{array}{l}\text { Entering contract }=\text { low } \\
\text { Maintaining contract }=\text { low }\end{array}$ & $\begin{array}{l}\text { Price = high } \\
\text { Milk delivery = low } \\
\text { Payment = low }\end{array}$ \\
\hline
\end{tabular}

milk assessing the quality of the road in a similar way. Transport itself was not considered a major problem.

Table 6 summarizes the level of search, contract, and enforcement costs of the 2 types of buyers of milk. The relationships between farmers and small dairies were based on maintaining good social relations, with search and contract costs of entering and maintaining milk delivery to small processors being high for farmers and processors alike. Even though the price level was fixed, considerable monitoring and enforcement costs were incurred to secure milk delivery and payment. High levels of trust between farmers and small processors reduced these costs to some extent, although entering milk delivery to the large processor involved low searching and contract costs as long as quantity restrictions were met. Because prices were variable, the main source of uncertainty arose from the possibility of opportunistic behavior by the processor regarding the results of milk quality tests.

Comparing Sales of Milk with Sales of Cheese. Whereas farmers selling milk traded with companies that processed the milk, those who sold cheese dealt with final consumers. Cheese was sold in a spot-market arrangement, whereas milk was sold on a (oral or written) contractual basis. Half of the farmers selling cheese found written contracts not important; this share was higher than for farmers selling milk, of whom $20 \%$ or less found it not important. Furthermore, most of the farmers selling cheese were neutral with regard to satisfaction with their contract $(60.7 \%)$, whereas farmers selling milk gave more diverse answers.

The risk of not being paid was equally low, and farmers selling cheese said they were mostly paid on time. Slightly more farmers selling cheese perceived that they could negotiate on prices (about 95\% of the farmers selling milk in the sample indicated that they could not bargain on the price, whereas this was perceived by $78 \%$ of the farmers selling cheese).

With regard to transport costs, most farmers selling cheese $(97 \%)$ indicated that the road to the market was good; in contrast, most farmers selling to the large dairy observed that the road was average (15\%), poor $(31 \%)$, or very poor $(15 \%)$. Transport was not con- sidered a major problem by most the farmers selling cheese $(77 \%)$.

In sum, there are significant differences in attributes of transaction costs in the comparison of contracts for the sale of milk than when comparing the contracts for sales of milk and sales of cheese. A possible explanation is that farmers adapt the type of institutional arrangement to the type of product but in such a way that transaction costs are minimized. In the case of cheese, the most beneficial seemed to be to sell directly to the consumers at the farm gate or local market on a spot-market basis. Selling cheese at the local market furthermore overcomes the transport problems related to perishable milk.

One important aspect not covered in our study is how changes in the policy and market environment could influence the farmers' development. Furthermore, an in-depth analysis of the supply chain is needed to reveal the distribution of bargaining power over the different actors and to analyze the importance of milk quality determination. Moreover, it would be interesting to investigate the possibilities for collective action by farmers because this may reduce both transport and transaction costs. This is left for future work.

\section{CONCLUSIONS}

Keeping dairy sheep is an important enterprise in rural FYR Macedonia because sheep may bring about multiple outputs in different markets. The rapid demise of the socialist market structure in the early 1990s has changed the rural economy significantly. We find that the uptake of new market arrangements is limited by location and production scale. The location of farms vis-à-vis the collection points of large dairy enterprises and the question of whether minimum quantities could be supplied were the primary quantifiable determinants of choice between small and large dairy companies. Additionally, the contracts of small and large dairies differed with regard to method of price fixation and security of timely payment. When given the choice, farmers showed a preference for large dairies with their secure payments despite the less transparent method of 
price determination. In some locations, farmers had the additional option of processing the milk on-farm into cheese and selling cheese. As such, the farmer's decision to engage in 1 of 3 different institutional arrangements (spot-market sales of cheese, informal contracts with the small processor, and formal contracts with the large processor) can be explained by their institutional environment, particularly the accessibility of the respective market opportunity in geographical terms, as well as the level of transaction costs. These results, however, imply that large processing companies have room to expand outreach in remote areas, through outreach deepening (i.e., increasing milk production by those farmers who already supply to large dairies) or outreach widening (i.e., by installing more collection points or opening new processing companies).

\section{REFERENCES}

Allen, D. 2000. Transaction Costs. Pages 893-926 in Encyclopaedia of Law and Economics. Volume One: The History and Methodology of Law and Economics. B. Bouckaert, and G. De Geest, ed. Edward Elgar Press, Cheltenham, UK. http://encyclo.findlaw. com/0740book.pdf Accessed July 2009

Doyon, M., G. Criner, and L. A. Bragg. 2008. Milk marketing policy options for the dairy industry in New England. J. Dairy Sci. 91:1229-1235.

Dzabirski, V., and S. Andonov. 1997. Sheep and goat husbandry in the former Yugoslav Republic of Macedonia. Paper presented at the FAO workshop: Sheep and Goat Husbandry in the Central and Eastern European Countries-A Struggle to Survive, Budapest. FAO, Rome, Italy.

Greene, W. H. 2000. Econometric Analysis. 4th ed. Prentice Hall International, Upper Saddle River, NJ.

GS. 2003. Spring Lamb Export Study, Macedonian Agricultural Competitiveness and Market Integration Study. GS Consultants and Lincoln University, Oakland, CA.

Gürsoy, O. 2006. Economics and profitability of sheep and goat production in Turkey under new support regimens and market conditions. Small Rumin. Res. 62:181-191.

Haenlein, G. F. W. 2001. Past, present and future perspectives of small ruminant dairy research. J. Dairy Sci. 84:2097-2115.
Haenlein, G. F. W. 2007. About the evolution of goat and sheep milk production. Small Rumin. Res. 68:3-6.

Hobbs, J. E. 1997. Measuring the importance of transaction costs in cattle marketing. Am. J. Agric. Econ. 79:1083-1095.

Holloway, G., C. Nicholson, C. Delgado, S. Staal, and S. Ehui. 2000. Agro-industrialisation through institutional innovation. Transaction costs, cooperative and milk-market development in the east-African highlands. Agric. Econ. 23:279-288.

Liefert, W., and J. Swinnen. 2002. Changes in Agricultural Markets in Transition Economies. Agricultural Economic Report, USDA, Washington, DC

MASA. 2001. Agricultural development strategy in the Republic of Macedonia to 2005. Macedonian Academy of Sciences and Arts, Ministry of Agriculture, Forestry and Water Economy, Skopje, FYR Macedonia.

Masten, S. E. 1996. Empirical Research in Transaction Cost Economics, Challenges, Progress and Directions. Pages 43-64 in Transaction Cost Economics and Beyond. J. Groenewegen, ed. Kluwer Academic Publishers, Boston, MA.

Niznikowski, R., E. Strzelec, and D. Pielarczyk. 2006. Economics and profitability of sheep and goat production under new support regimens and market conditions in Central and Eastern Europe. Small Rumin. Res. 62:159-165.

Poate, C. D., and P. F. Daplyn. 1993. Data for Agrarian Development. Cambridge University Press, Cambridge, UK.

SSO. 2005. Statistical Tables. State Statistical Office of the Republic of Macedonia, Skopje, FYR Macedonia.

Staal, S., C. Delgado, and C. Nicholson. 1997. Smallholder dairying under transaction costs in East Africa. World Dev. 25:779-794.

Tsourgiannis, L., J. Eddison, and W. Warren. 2008. Factors affecting the marketing channel choice of sheep and goat farmers in the region of east Macedonia in Greece regarding the distribution of their milk production. Small Rumin. Res. 79:87-97.

WDI. 2007. World Development Indicators. World Bank, Washington, DC

Williamson, O. E. 1979. Transaction-cost economics: The governance of contractual relations. J. Law Econ. 22:233-261.

Wolfová, M., J. Wolf, Z. Krupová, and M. Margetín. 2009. Estimation of economic values for traits in dairy sheep: II. Model application to a production system with one lambing per year. J. Dairy Sci. 92:2195-2203.

World Bank. 2002. FYR Macedonia Agricultural Sector Review 2002. World Bank, Washington, DC.

World Bank. 2003. Trade Policies and Institutions in the Countries of South Eastern Europe and the UE Stabilization and Association Process. Background Country Studies, 2003. World Bank, Washington, DC 